\title{
ANALISIS KEBIJAKAN E-PROCUREMENT DI PEMERINTAH PROVINSI GORONTALO MENGGUNAKAN METODE TECHNOLOGY ACCEPTANCE MODEL DANEND USER COMPUTING SATISFACTION
}

\author{
Jorry Karim ${ }^{1}$ dan Marlin Lasena ${ }^{2}$ \\ 1oyie.potlot@gmail.com, ${ }^{2}$ marlinlasena@gmail.com \\ ${ }^{12}$ STMIK ICHSAN GORONTALO
}

\begin{abstract}
Abstrak
Penelitian ini bertujuan untuk mengetahui keberhasilan implementasi e-procurement di Provinsi Gorontalo dengan menggunakan Metode Model Akselerasi Teknologi (TAM dari Davis) dan Kepuasan Pengguna Akhir (EUCS dari Doll dan Torkzadeh). Evaluasi difokuskan pada komponen inti dalam keberhasilan implementasi e-procurement yaitu kualitas informasi, kualitas sistem, kualitas layanan, kepuasan pengguna, penggunaan sistem, dan manfaat bersih. Pengaruh dan hubungan antar komponen ini diuji dengan menggunakan metode kuantitatif dengan analisis pemodelan persamaan struktural (SEM) dengan menggunakan AMOS. Instrumen yang digunakan untuk mengukur dimensi yang mempengaruhi keberhasilan pelaksanaan e-procurement adalah kuesioner yang dekat dari persepsi pengguna dengan menggunakan skala Likert 1 sampai 5 . Ada sebanyak 187 sampel yang kembali diantara 225 sampel e-procurement. Hasil analisis menunjukkan bahwa kualitas informasi berpengaruh signifikan terhadap penggunaan sistem dan kepuasan pengguna. kemudahan penggunaan, isi, keakuratan, format, kemudahan, ketepatan waktu memiliki pengaruh positif kepuasan kepuasan pengguna yang signifikan. Dalam penelitian ini review terhadap analisa teknikal juga dilakukan dengan membandingkan keberhasilan implementasi e-procurement dari persepsi pengguna terhadap kondisi aktual implementasi teknis e-procurement.
\end{abstract}

Kata kunci: e-procurement, kegunaan, kemudahan, akurasi, ketepatan.

\section{Pendahuluan}

Pengadaan barang atau jasa secara elektronik (e-procurement) telah menarikperhatian besar dalam beberapa tahun terakhir ini. Pemerintah Indonesia telahmenjadikan e-procurement sebagai salah satu dari 7 (tujuh) flagship Teknologiinformasi dan komunikasi Nasional melalui Lembaga Kebijakan PengadaanBarang atau Jasa Pemerintah. Penerapan e-procurement tersebut bertujuan untuktransparansi, efisiensi dan efektifitas, serta akuntabel dalam pengadaanbarang atau jasa melalui media elektronik antara panitia dan penyedia barang atau jasa.[2]

Pemerintah Provinsi Gorontalo yang dikenal dengan berbagai program inovasinya mencoba melakukan terobosan inovatif dengan memanfaatkan kehadiran teknologi informasi demi mewujudkan percepatan pelayanan publik.

Dengan berdasarkan Keputusan Presiden No. 80 Tahun 2003 tentang Pedoman Pelaksanaan Pengadaan Barang/Jasa Pemerintah dan Instruksi Presiden No. 5 Tahun 2004 tentang Percepatan Pemberantasan Korupsi, maka pada tahun 2008 Pemerintah Provinsi Gorontalo mulai menerapkan eprocurement.

Penerapan e-procurement ini berdasarkan Surat Keputusan Gubernur Gorontalo No. 45 tahun 2008 tentang Pedoman Pelaksanaan Pengadaan Barang/Jasa Secara Elektronik Berbasis Internet (eprocurement) melalui Layanan Pengadaan Secara Elektronik (LPSE) Provinsi Gorontalo. Aplikasi yang digunakandalam e-procurement merupakan aplikasi yang dikembangkan oleh LKPP pada tahun 2008. Penerapan e-procurement ini dilaksanakan dalam rangka proses pengadaan barang/jasa yang lebih transparan, akuntabel, efektif dan efisien, selaras dengan upaya pemberantasan korupsi, kolusi dan nepotisme.[5].

Karena kesuksesan sebuah sistem informasi dipengaruhi oleh sikap pengguna terhadap sistem tersebut, maka masalah penelitiannya adalah:

Sejauh mana penerimaan pengguna terhadap penerapan e-procurement berdasarkan Technology Accpetance Model (TAM dari Davis) dan End User Computing Satisfaction (EUCS dari Doll dan Torkzadeh). 


\section{Metode \\ Pengembangan Hipotesis Pengaruh Isi (content) dan Akurasi (accuracy) terhadap Kemanfaatan (usefullnes) Penggunaan Sistem e-procurement.}

Secara teoritis kemanfaatan yang dipercayai oleh pemakai dapat mempertinggi prestasi kerjanya mendorong pemakai secara psikologis untukmenerima penggunaan Teknologi Informasi dalam pekerjaannya. Igbaria.et.al (1997) melakukan penelitian di Negara Selandia Baru dengan jumlah sampel 203 perusahaan kecil pemakai Teknologi Informasi. Hasil penelitian tersebut membuktikan bahwa akurasi memiliki hubungan terhadap penerimaan penggunaan PC diperusahaan kecil. Untuk mendukung konsistensi hasil penelitian-penelitian yang dilakukan sebelumnya, hipotesis 1 dinyatakan sebagai :

Hipotesis 1 :Isi (content) berpengaruh secara positif terhadap kemanfaatan (usefulness) penggunaan sistem e-procurement.

Hipotesis 2 :Akurasi (accuracy) berpengaruh secara positif terhadapkemanfaatan (usefulness) penggunaan sistem e-procurement.

\section{Pengembangan Hipotesis Pengaruh Bentuk (format) terhadap Kemanfaatan (usefulness) Penggunaan Sistem e-procurement}

Secara teoritis telah dijelaskan bahwa penerimaan pemakai Teknologi Informasi turut di pengaruhi oleh kemudahan penggunaan Teknologi Informasi, ini merupakan refleksi psikologis pemakai yang lebih bersikap terbuka terhadap sesuatu yang sesuai dengan apa yang di pahaminya dengan mudah. Davis F.D (1989) mengidentifikasi bahwa kemudahan penggunaan mempunyai pengaruh terhadap penerimaan penggunaan komputer.[7]

Kesimpulannya adalah penerimaan penggunaan Teknologi Informasi turut dipengaruhi oleh kemudahan penggunaan Teknologi Informasi, makahipotesis 2 dinyatakan :

Hipotesis 3: bentuk (format) berpengaruh secara positif terhadap kemanfaatan (usefulness) penggunaan sistem e-procurement.

\section{Pengembangan Hipotesis Pengaruh Kepuasan Pengguna Akhir (End User Computing Satisfaction) terhadap Penerimaan Penggunaan e-procurement}

Sistem informasi suatu organisasi dapat diandalkan apabila memiliki kualitas yang baik dan mampu memberikan kepuasan pada pemakainya. Dengan adanya kepuasan pemakai tersebut maka akan timbul penerimaan (acceptance) pada sistem informasi yang dipergunakan dalam organisasi tersebut. Kepuasan pemakai (usersatisfaction) merupakan salah satu indikator dari keberhasilan pengembangan system informasi (Bailey, 1983). Menurut Doll dan Torkzadeh (1998) melakukan pengukuran terhadap kepuasan pemakai akhir sistem (End User ComputingSatisfaction) dengan mengembangkan instrumen yang terdiri dari 5 komponen yaitu:

Isi (content), Akurasi (accuracy), Bentuk (format), Kemudahan (ease) dan Ketepatan Waktu (timeliness), yang meliputi 20 item pertanyaan. Kesimpulannya adalah penerimaan penggunaan Teknologi Informasi turut dipengaruhi oleh kepuasan pemakai terhadap penggunaan Teknologi Informasi, maka hipotesis dinyatakan sebagai berikut:

Hipotesis 4: Ketepatan waktu (timeliness)berpengaruh secara positif terhadap kemudahan penggunaan (ease of use)e-procurement.

Hipotesis 5: Kemanfaatan (usefulness)) berpengaruh secara positif terhadap kepuasan pengguna (user satisfaction)e-procurement.

Hipotesis 6: Akurasi (accuracy) berpengaruh secara positif terhadap kepuasan pengguna (user satisfaction) penggunaan e-procurement.

Hipotesis 7: Kemudahan (ease) berpengaruh secara positif terhadap kepuasan pengguna (user satisfaction)e-procurement.

Hipotesis 8 : Kemudahan penggunaan (ease of use) berpengaruh secara positif terhadap kepuasan pengguna (user satisfaction) e-procurement.

Dalam penelitian ini menggabungkan 2 (dua) model sebagai kerangka pemikiran teoritis yaitu Technology Acceptance Model (TAM) dan End UserComputing Satisfaction (EUCS) dalam lingkungan penggunaan sistem informasi yang bersifat mandatory use. Berdasarkan uraian sebelumnya, maka kerangka pemikiran konseptual untuk pengujian Hipotesis 1 dan Hipotesis 2 yang didasarkan pada Technology Acceptance Model (TAM) yang dikembangkan oleh Davis F.D(1989) yang kemudian diadopsi oleh Sefan Linders (2004) mengenai penerapanTechnology Acceptance Model (TAM) dalam lingkungan mandatory system dan untuk hipotesis 3 - hipotesis 6 didasarkan pada End User Computing Satisfaction (EUCS) yang dikembangkan oleh Doll dan Torkzadeh (1988). 


\section{E- Procurement}

Menurut Peraturan Pemerintah No. 24 Tahun 2010, Pengadaan secara elektronik atau E-Procurement adalah Pengadaan Barang/Jasa yang dilaksanakan dengan menggunakan teknologi informasi dan transaksi elektronik sesuai dengan ketentuan perundang-undangan. Sedangkan menurut Australian Government Information Management (AGIMO), e-Procurement merupakan pembelian antar-bisnis (business-to-business, B2B) dan penjualan barang dan jasa melalui internet. [6]

KonsepE-Procurement

Berikut ini adalah diagram e-procurement management, sebagai berikut:

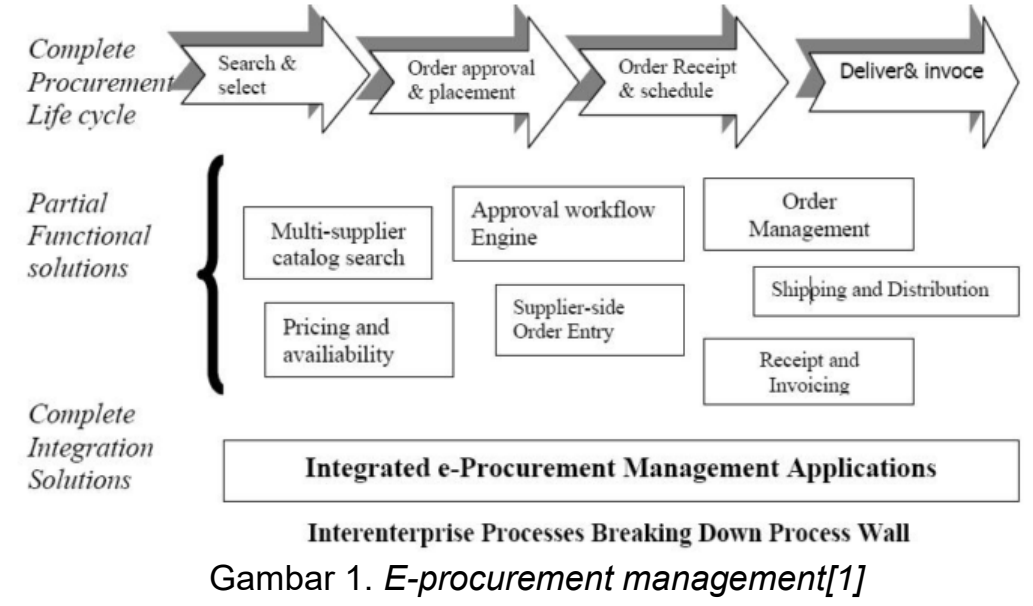

\section{Technology Acceptance Model (TAM)}

TAM merupakan adaptasi dari Theory of Reasoned Action Model (TRA)yang secara khusus telah disesuaikan dengan model penerimaan sistem informasi oleh pengguna/user (Davis et aL,1989) yang kemudian diadopsi oleh Sefan Linders (2004) mengenai penerapan Technology Acceptance Model (TAM) dalam lingkungan mandatory system.[3]

\section{Kemanfaatan (Usefulness) Pemakai}

Davis F.D (1989) mendefinisikan kemanfaatan (usefulness) yaitu: "Thedegree to which a person believes that using particular system would enhance his orher job performance". Hal tersebut dapat diartikan sebagai suatu tingkatan dimana seseorang percaya bahwa penggunaan suatu sistem tertentu akan dapat meningkatkan prestasi kerja orang tersebut. Menurut Thompson.et.al (1991) kemanfaatan TI merupakan manfaat yang diharapkan oleh pemakai TI dalam melaksanakantugasnya. Pengukuran kemanfaatan tersebut berdasarkan frekuensi penggunaan dan diversitas/keragaman aplikasi yang dijalankan. Thompson.et.al, (1991) juga menyebutkan bahwa individu akan menggunakan $\mathrm{TI}$ jika mengetahui manfaat positif atas penggunaannya.

\section{Kemudahan Penggunaan (Ease of Use)}

Davis F.D (1989) mendefinisikan kemudahan penggunaan (ease of use) adalah: "Refers to the degree to which person believes that using a particular systemwould he free of effort". Hal tersebut dapat diartikan sebagai suatu tingkatan dimana seseorang percaya bahwa penggunaan sistem tertentu dapat mengurangi usaha seseorang dalam mengerjakan sesuatu. Menurut Goodwin (1987); Silver (1998);dalam Adam.et.al (1992), intensitas penggunaan dan interaksi antara pemakai dengan sistem juga dapat menunjukkan kemudahan penggunaan. Sistem yang lebih sering digunakan menunjukkan bahwa sistem tersebut lebih dikenal, lebih mudah dioperasikan dan lebih mudah digunakan oleh pemakainya.

\section{End User Computing Satisfaction (EUCS)}

Model ini dikembangkan oleh Doll dan Torkzadeh (1988) yang digunakan untuk mengukur kepuasan pemakai akhir komputer. Mereka mengembangkan instrumen pengukur kepuasan yaitu instrumen end user computing satisfaction (EUCS). Doll dan Torkzadeh mengembangkan instrumen EUCS yang terdiri dari 12 item dengan membandingkan lingkungan pemrosesan data tradisional dengan lingkungan end user computing, yang meliputi 5 komponen: Isi (content), Akurasi (accuracy), Bentuk (format), Kemudahan (ease) dan Ketepatan Waktu (timeliness). 


\section{Pelaksanaan Penelitian Bahan Penelitian}

Bahan penelitian adalah e-procurement yang telah diterapkan pada pemerintah Provinsi Gorontalo. Sumber data yang menjadi bahan penelitian ini meliputi data primer dan data sekunder. Data sekunder diperoleh dari kajian pustaka dan studi literatur berupa buku-buku teks, jurnal, majalah, internet, bahan praktikum kuliah, hasil penelitian terdahulu serta data pada pemerintah Provinsi Gorontalo yang meliputi penerapan teknologi informasi. Data ini digunakan untuk mendapatkan teoriteori yang mendukung penelitian ini, yaitu sistem informasi, e-procurement, kesuksesan sistem informasi, Technology Acceptance Model (TAM) dan End User Computer Satisfaction (EUCS) serta analisis statistik.

\section{Alat Penelitian}

Penelitian ini mengunakan kuesioner sebagai alat untuk mengukur dimensi-dimensi yang mempengaruhi kesuksesan penerapan e-procurement di pemerintah Provinsi Gorontalo dengan mengadopsi Technology Acceptance Model (TAM) dan End User Computer Satisfaction (EUCS). Jenis kuesioner yang digunakan adalah kuesioner tertutup dimana responden memilih jawaban yang sudah tersedia sesuai dengan penilaian responden. Setelah item-item kuesioner telah didefinisikan untuk dapat diukur, maka diperlukan alat untuk mengukurnya yaitu disebut dengan skala (Jogiyanto, 2008, h. 128). Skala yang digunakan pada kuesioner adalah skala Likert 1 sampai dengan 5 dengan kategori jawaban setuju, tidak setuju, netral, setuju dan sangat setuju (Ghozali, 2008, h.11). Kemudian hasil dari pengukuran dengan kuesioner akan dianalisis dengan structural equation model (SEM) dengan menggunakan software statistik AMOS VER. 20.

\section{Jalan Penelitian}

Penelitian akan dilakukan dalam beberapa tahapan untuk mendapatkan jalan penelitian yang sistematis, tahapan yang dilakukan adalah sebagai berikut:

\section{Tahap Awal}

Tahap awal dilakukan pengumpulan data dengan cara studi literatur dari buku, jurnal dan artikel yang berhubungan dengan tema penelitian. Bahan yang telah dikumpulkan digunakan untuk menyelesaikan masalah. Pada tahap ini diindentifikasi variabel-variabel yang akan diteliti. Menurut (Ghozali, 2008, h. 6) variabel yang digunakan dalam model persamaan struktural terdiri dari variabel exogen yaitu variabel yang tidak dipengaruhi oleh variabel anteseden (sebelumnya), variabel endogen yaitu variabel yang dipengaruhi oleh variabel sebelumnya, dan variabel endogen intervening atau mediating yaitu variabel yang memiliki anteseden dan konsekuen (variabel sesudahnya). Dari Technology Acceptance Model (TAM) dan End User Computer Satisfaction (EUCS) dapat diidentifikasi variabel yang digunakan pada penelitian ini adalah sebagai berikut:

\section{Tahap Pemecahan Masalah}

Tahapan pemecahan masalah, akan menentukan model yang akan digunakan untuk memecahkan masalah yang telah dirumuskan. Penyelesaian masalah menggunakan Technology Acceptance Model (TAM) dan End User Computer Satisfaction untuk (EUCS) menganalisis keberhasilan dan kesuksesan e-procurement. Metode pengambilan sampel yang digunakan dalam penelitian ini adalah purposive sampling, dilakukan dengan mengambil sampel dari populasi berdasarkan suatu kriteria tertentu yang sudah ditetapkan (Jogiyanto, 2008, h. 76). Populasi dalam penelitian adalah entitas yang terlibat dalam e-procurement pemerintah Provinsi Gorontalo yaitu PPK, panitia, penyedia barang/jasa dengan jumlah populasi 861 responden. Kriteria yang digunakan dalam pengambilan sampel yaitu calon responden yang sudah terverifikasi (sudah menggunakan proses eprocurement) dengan jumlah sampel 225 responden. Kuesioner akan digunakan untuk melakukan penilaian terhadap masing-masing variabel dengan jenis kuesioner tertutup dimana responden memilih jawaban yang ada pada kuesioner.

\section{Tahap Analisis}

1. Validitas dan Reliabilitas

Analisis pertama yang dilakukan adalah uji validitas dan reliabilitas terhadap pertanyaanpertanyaan yang digunakan dalam kuesioner. Umumnya suatu penelitian menggunakan item-item konstruk sebagai kuesioner yang sudah digunakan pada penelitian sebelumnya. Jika terpaksa karena tidak ada item-item konstruk pada penelitian sebelumnya, maka item-item konstruk tersebut harus dibangun dengan melakukan uji validitas dan reliabilitas terlebih dahulu (Jogiyanto, 2008, h. 136-137). 2. Analisis dengan SEM

Analisis yang kedua dilakukan pengujian hipotesis terhadap data-data primer yang diperoleh dari hasil uji lapangan. Analisis ini menggunakan model persamaan dengan SEM. Menurut Sugiyono 
(2008, h. 323) di dalam analisis pemodelan persamaan struktural (SEM) dapat dilakukan tiga macam kegiatan serentak, yaitu pengecekan validitas dan reliabilitas instrumen (berkaitan dengan analisis faktor konfirmasi), pengujian model hubungan antar variabel (berkaitan dengan analisis jalur), dan kegiatan untuk mendapatkan suatu model yang cocok untuk prediksi (berkaitan dengan analisis regresi atau analisis model struktural).

3. Analisis Kualitatif

Analisa yang ketiga dilakukan identifikasi permasalahan dengan mencari penjelasan pada hipotesis yang tidak terbukti atau ditolak dengan menggunakan analisis kualitatif. Analisis kualitatif dilakukan dengan metode melakukan kajian dari literatur-literatur best practice dalam implementasi eprocurement, mencari informasi melalui dokumen-dokumen pemerintahan, wawancara dan FGD (Focused Group Discussion) dengan pihak yang terkait dalam pelaksanaan sistem e-procurement pemerintah Provinsi Gorontalo.

\section{Uji Hipotesis}

Untuk pengujian seluruh hipotesis maka digunakan analisi data dengan SEM dengan bantuan software AMOS. Hal ini disebabkan karena keseluruhan data kuisioner yang terkumpul dari responden berjumlah 187 responden. Hal ini sesuai dengan syarat jumlah responde yang dapat diolah dengan menggunakan software AMOS antara 100 sampai 800 (Imam Ghozali, 2006).

Dengan uji $t$, yaitu untuk menguji signifikansi konstanta dan variable independen yang terdapat dalam persamaan tersebut secara individu apakah berpengaruh terhadap nilai variabel dependen (Imam Ghozali, 2001). Untuk pengujian ini dilakukan dengan melihat output dengan bantuan aplikasi AMOS. Jika nilai $\mathrm{T}$ hitung $>\mathrm{T}$ tabel, maka Hipotesis nol ditolak, (koefisien regresi signifikan) dan Hipotesis alternatif yang dinyatakan dalam penelitian ini diterima pada tingkat signifikansi 5\% (lima persen). Model persamaan struktural dalam penelitian ini akan diselesaikan dengan program AMOS VER. 20.

\section{Hasil dan Pembahasan}

\section{E-Procurement Pemerintah Provinsi Gorontalo}

E-procurement merupakan proses pengadaan barang/jasa pemerintah yang pelaksanaannya dilakukan secara elektronik yang berbasis web/internet dengan memanfaatkan fasilitas teknologi komunikasi dan informasi agar proses pengadaan barang/jasa akan lebih transparan, akuntabel, efektif dan efisien, selaras dengan upaya pemberantasan korupsi, kolusi dan nepotisme. Dalam penerapannya, e-procurement di pemerintah Provinsi Gorontalo dikelola oleh Layanan Pengadaan Secara Elektronik (LPSE) Provinsi Gorontalo yang dibentuk berdasarkan Surat Keputusan Gubernur Gorontalo Nomor 45 tahun 2008.

\section{Informasi, Sistem dan Layanan dalam E-Procurement}

Informasi yang dihasilkan oleh e-procurement dapat diakses oleh publik melalui media internet. Untuk dapat mengikuti proses e-procurement perusahaan harus mendaftar sebagai rekanan terlebih dahulu. Pendaftaran menjadi rekanan dapat dilakukan melalui aplikasi e-procurement. Informasi yang dapat diakses oleh publik dapat dilihat pada gambar 4.1. 


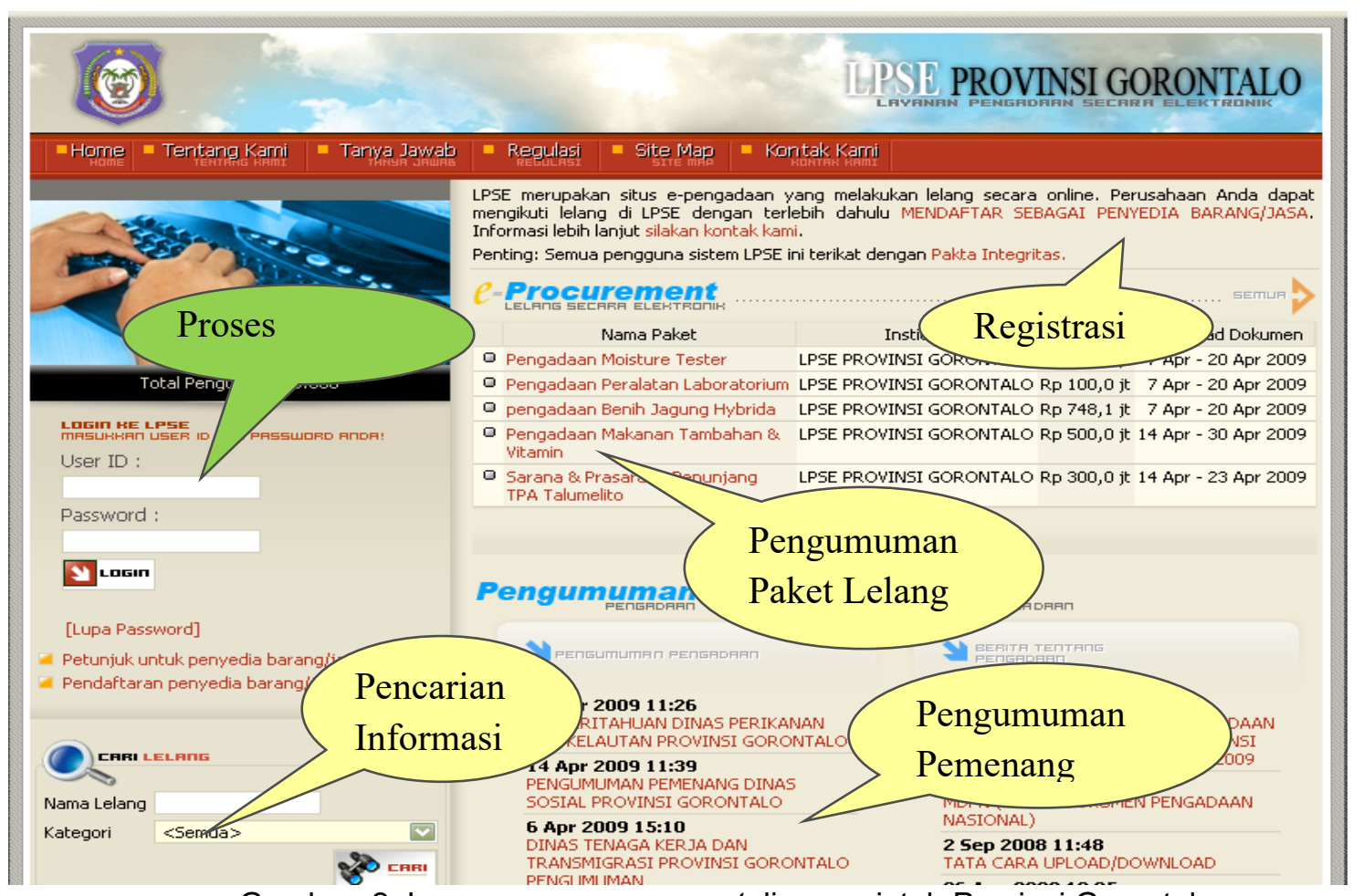

Gambar 2. Layanan e-procurement di pemerintah Provinsi Gorontalo

\section{Proses dalam E-Procurement}

Proses pengadaan barang/jasa pemerintahan baik konvensional maupun secara elektronis (eprocurement) harus mengacu kepada Keppres Nomor 80 Tahun 2003 tentang Pedoman Pelaksanaan Pengadaan Barang/Jasa Pemerintah, serta regulasi-regulasi pendukungnya, tahapan proses pengadaan tersebut dapat dilihat pada gambar $4.2 \mathrm{a}$.dan $4.2 \mathrm{~b}$

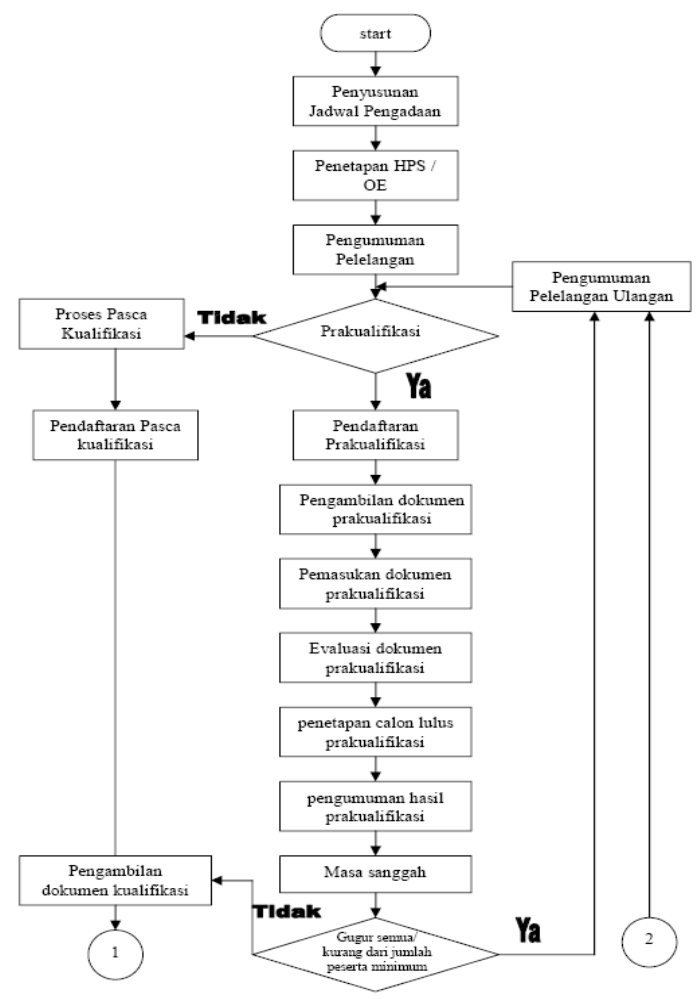

Gambar 3. Proses pengadaan barang/jasa berdasarkan Keppres No. 80 Tahun 2003 


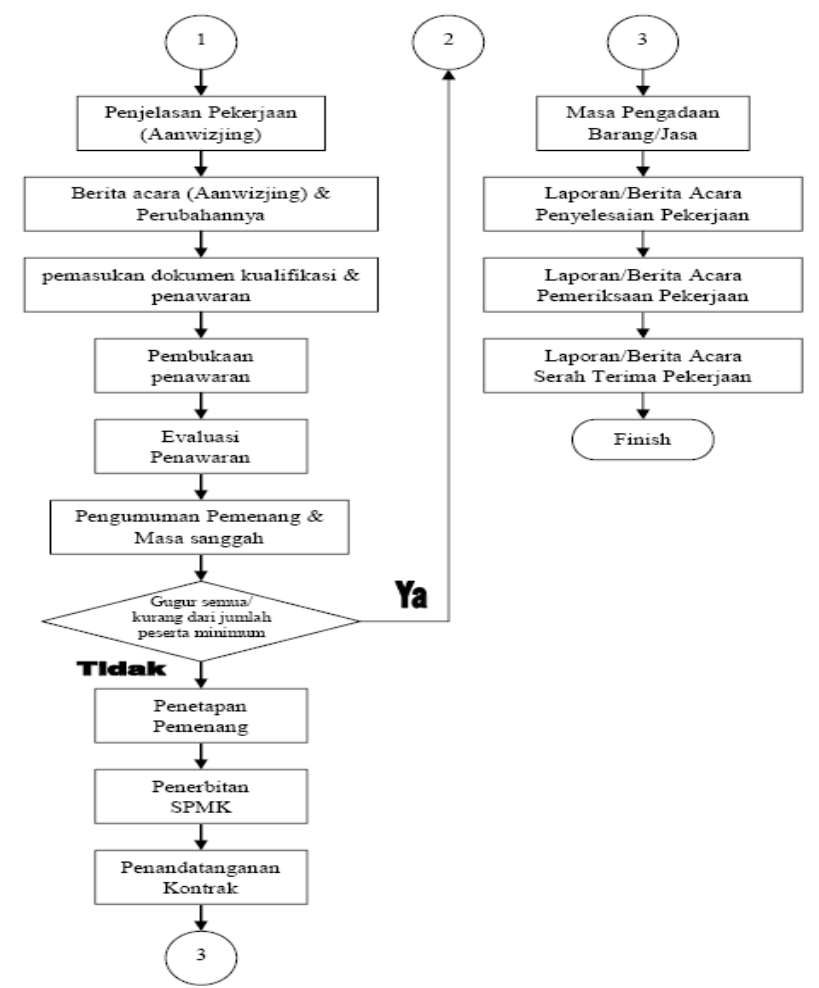

Gambar 4. Proses pengadaan barang/jasa berdasarkan Keppres No. 80 Tahun 2003

\section{Hasil Pengujian Validitas dan Reliabilitas Instrumen}

Tabel 1. Hasil Uji Reliabilitas

\begin{tabular}{|l|l|l|}
\hline Variabel & Cronbach's Alpha & Keterangan \\
\hline Content & 0,614 & Reliabel \\
\hline Accuracy & 0,830 & Reliabel \\
\hline Format & 0,617 & Reliabel \\
\hline Ease & 0,748 & Reliabel \\
\hline Timeless & 0,642 & Reliabel \\
\hline Usefull & 0,714 & Reliabel \\
\hline Ease of Use & 0,606 & Reliabel \\
\hline User Satisfaction & 0,801 & Reliabel \\
\hline
\end{tabular}

Sumber: Data Primer yang Diolah, 2013

Nilai $r$ hitung merupakan hasil korelasi jawaban responden disetiap pertanyaan pada masingmasing variabel, prosesnya dilakukan dengan program SPSS versi 20.0 dengan nama outputnya corrected item total correlation. Sementara nilai $r$ tabel dengan menggunakan $r$ product moment diperoleh dengan menghitung degree of freedom $(\mathrm{df})=\mathrm{n}-2$, yaitu dengan $\mathrm{n}$ (sampel) 187 dengan sig $\alpha$ $=0,05$, sehingga 187-2 = 185 maka didapat $r$ tabel product moment sebesar 0,1207.

Adapun pernyataannya adalah sebagai berikut :

a. Nilai $r$ hitung $>$ dibanding $r$ tabel, maka dinyatakan valid.

b. Nilai $r$ hitung < dibanding $r$ tabel, maka dinyatakan tidak valid.

Hasil uji validitas menunjukkan bahwa nilai $r$ hitung setiap indikator lebih besar daripada nilai $r$ tabel, dengan demikian semua indikator variabel dinyatakan valid sebagai alat ukur variabel penelitian.

\section{Pengujian Hipotesis \\ Model Persamaan Struktural}

Model persamaan struktural atau Structural Equation Model (SEM) merupakan suatu teknik statistik peubah ganda yang mampu menganalisis variabel laten, variabel indikator dan kesalahan pengukuran secara langsung. Model persamaan struktural memiliki dua tujuan utama dalam analisisnya, yaitu untuk menentukan apakah suatu model masuk akal atau sesuai berdasarkan data yang dimiliki, serta menguji berbagai hipotesis yang telah dibangun sebelumnya. 


\section{Analisis Data}

Analisis data untuk pengujian hipotesis pada penelitian ini menggunakan software AMOS. Alasan pemilihan software ini karena AMOS merekomendasikan jumlah sampel dari 100 sampai 800 sampel (Ghozali, 2008a. h.5).Gambar 4.8 menampilkan diagram jalur hasil estimasi model untuk pengujian hipotesis dengan software AMOS Ver. 20. Nilai chi-square sebagai kriteria model fit paling fundamental bernilai ) 0,716 dengan probabilitas ( $p$ ) sebesar 0,398. Hasil ini menunjukkan bahwa model fit karena nilai $p>0,05$, yang berarti data observasi signifikan dengan model/teori .

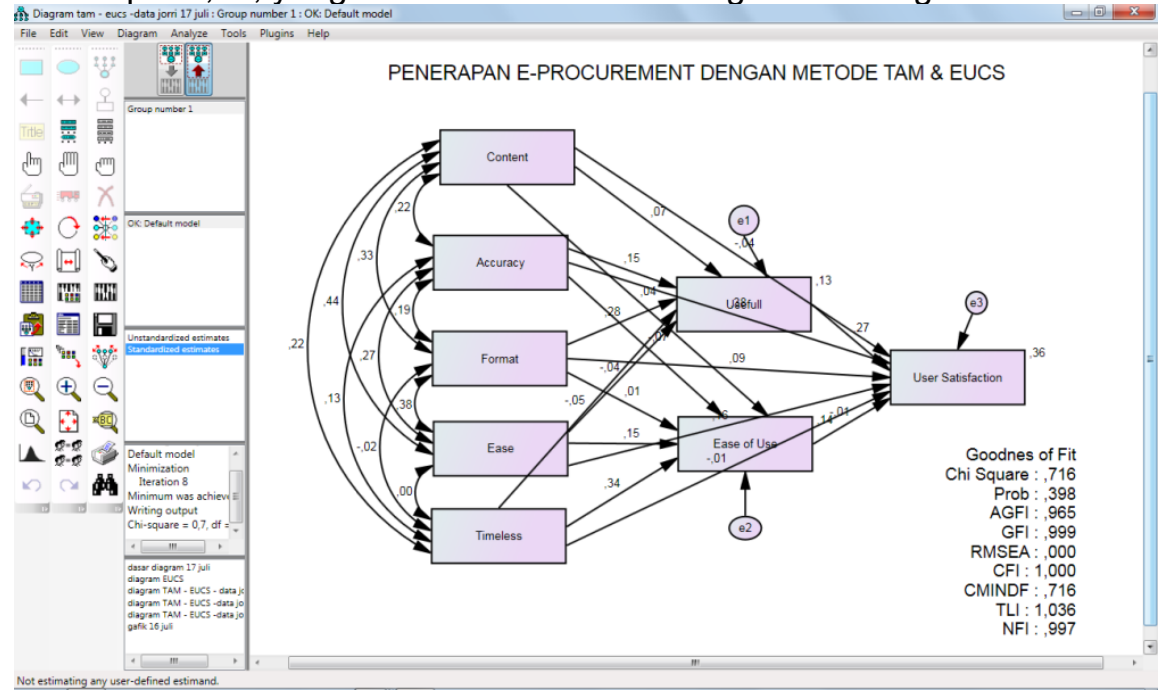

Gambar 5. ODiagram jalur untuk uji hipotesis pada software AMOS Ver. 20

Dari di atas diketahui bahwa hasil pengujian terhadap asumsi-asumsi model persamaan struktural adalah sebagai berikut:

1. Ukuran Sampel

Jumlah sampel dalam penelitian adalah 187, dianggap sudah cukup memenuhi syarat karena ukuran sampel yang disarankan untuk melakukan metode estimasi Maximum Likelihood adalah 100 200 sampel.

1. Uji Overall Model Fit

Gambar 4.3 menunjukkan nilai chi-square sebesar 0,716 dengan nilai CMIN/DF sebesar 0,716 dan probabilitas ( $p$ ) sebesar 0,398 .Nilai-nilai tersebut sudah sesuai dengan nilai yang dianjurkan yaitu nilai CMIN/DF $<2,0$ dan nilai $p \geq 0,05$. Hal ini membuktikan bahwa input matrik kovarian antara data observasi dengan model/teori tidak berbeda secara signifikan atau dengan kata lain model dapat dianggap sudah cukup fit.

2. Analisis Faktor Konfirmatori dan Validitas Konstruk

Menurut Ghozali salah satu manfaat utama dari analisis faktor konfirmatori adalah kemampuan menilai validitas konstruk dari measurement theory yang diusulkan. Validitas konstruk mengukur sampai seberapa jauh ukuran indikator mampu merefleksikan konstruk laten teoritis. Jadi validitas konstruk memberikan kepercayaan bahwa ukuran indikator yang diambil dari sampel menggambarkan skor sesungguhnya di dalam populasi. Ada empat ukuran validitas konstruk yaitu Convergent Validity, Variance Extraced, Reliability dan Discriminat Validity.

3. Uji Hipotesis

Menurut Sugiono hipotesis dalam penelitian merupakan jawaban sementara terhadap rumusan masalah penelitian. Pengujian hipotesis ditolak atau diterima ditentukan oleh level of significant atau tingkat signifikansi. Biasanya tingkat signifikansi yang diambil adalah $1 \%$ dan $5 \%$.

Pengujian terhadap hipotesis yang diajukan pada AMOS Ver. 20 dapat dilihat pada koefisien standardized regression. Sebuah konstruk berpengaruh signifikan terhadap konstruk yang lain jika probabilitas hubungan kedua konstruk tersebut bernilai lebih kecil atau sama dengan 0,05.

Keseluruhan hasil estimasi pada penelitian ini dapat dilihat pada tabel 4.1

Tabel 2. Estimasi hasil penelitian

\begin{tabular}{|l|l|l|l|l|l|}
\hline \multirow{2}{*}{ Hipotesis } & Jalur & \multirow{2}{*}{ Estimate } & C.R. & P \\
\cline { 2 - 3 } & Dari & ke & & \\
\hline
\end{tabular}


ILKOM Jurnal Ilmiah Volume 9 Nomor 3 Desember 2017

\begin{tabular}{|c|c|c|c|c|c|}
\hline $\mathrm{H}_{1}$ & $\mathrm{X} 1$ & $\mathrm{Y} 1$ & ,070 & ,830 & ,407 \\
\hline $\mathrm{H}_{2}$ & X2 & $\mathrm{Y} 1$ & ,151 & 2,101 & ,036 \\
\hline $\mathrm{H}_{3}$ & X3 & Y1 & ,258 & 3,701 & $* * *$ \\
\hline $\mathrm{H}_{4}$ & $\times 5$ & Y2 & ,398 & 4,803 & $* * *$ \\
\hline $\mathrm{H}_{5}$ & Y1 & Y3 & ,345 & 4,305 & $\star * *$ \\
\hline $\mathrm{H}_{6}$ & $\times 2$ & Y3 & ,488 & 6,137 & $\star \star \star *$ \\
\hline $\mathrm{H}_{7}$ & $\mathrm{X} 4$ & Y3 & ,295 & 2,258 & ,024 \\
\hline $\mathrm{H}_{8}$ & Y2 & Y3 &,- 007 &,- 084 &, 933 \\
\hline
\end{tabular}

Ket: ${ }^{* \star \star}=$ signifikan pada 0,01

Sumber: Data primer diolah 2013

\section{Pembahasan}

Pengujian terhadap seluruh hipotesis $\mathrm{H}_{1}$ sampai dengan $\mathrm{H}_{8}$ memberikan kesimpulan bahwa sebagian besar hipotesis tersebut dapat diterima, yang berarti bahwa komponen-komponen model Technology Acceptance Model (TAM) dan End User Computing Satisfaction terhadap penerapan e-procurement berpengaruh signifikan antara X2 terhadap Y1, X3 terhadap Y1, X5 terhadap Y2, Y1 terhadap Y2, X2 terhadap Y3, X4 terhadap Y3. Sementara X1 terhadap Y1 dan Y2 terhadap Y3 tidak berpengaruh positif terhadap penerapan e-procurement.

\section{Tinjauan Analisis Teknis}

Tinjauan analisis secara teknis dilakukan melalui observasi dan wawancara mendalam terhadap hasil-hasil yang diperoleh dari analisis kuantitatif dan persepsi pengguna. Observasi dilakukan pada proses e-procurement yang dilaksanakan dan wawancara dilakukan pada administrator PPE yaitu administrator yang level otoritasnya paling tinggi dalam sistem aplikasi.

\section{Kesimpulan dan Saran Kesimpulan}

Hasil analisis menunjukkan bahwa Akurasi (accuracy)berpengaruh secara positif terhadap kemanfaatan (usefulness) penggunaan sistem e-procurement, bentuk (format) berpengaruh secara positif terhadap kemanfaatan (usefulness)penggunaan sistem e-procurement, Ketepatan waktu (timeliness)berpengaruh secara positif terhadap kemudahan penggunaan (ease of use)eprocurement, Kemanfaatan (usefulness)) berpengaruh secara positif terhadap kepuasan pengguna (user satisfaction)e-procurement, Akurasi (accuracy) berpengaruh secara positif terhadap kepuasan pengguna (user satisfaction) penggunaan e-procurement dan Kemudahan (ease) berpengaruh secara positif terhadap kepuasan pengguna (user satisfaction)e-procurement.

Berdasarkan hasil analisis data penelitian yang telah dilakukan, maka dapat disimpulkan sebagai berikut:

1. Berpengaruhnya Akurasi (accuracy) dan bentuk (format) berpengaruh secara positif terhadap kemanfaatan (usefulness), maka diharapkan pihak manajemen organisasi yaitu sekretariat LPSE meningkatkan kualitas informasi, kualitas sistem, dan kualitas layanan karena peningkatan ini akan mempengaruhi peningkatan penggunaan e-procurement sehingga penggunaannya lebih optimal dan dapat menciptakan sistem pengadaan barang/jasa yang profesional, transparan sesuai dengan perundang-undangan yang berlaku.

2. Berpengaruhnya Kemanfaatan (usefulness), Akurasi (accuracy) dan Kemudahan (ease) berpengaruh secara positif terhadap kepuasan pengguna (user satisfaction)e-procurement, maka peningkatkan kualitas informasi, kualitas sistem, dan kualitas layanan akan mempengaruhi peninggkatan kepuasaan penggunaan aplikasi e-procurement sehingga proses pengadaan barang dan jasa sesuai dengan harga, kualitas dan tanggapan yang terbaik sehingga mempengaruhi peninggkatan kepuasaan PPK, panitia, dan penyedia barang/jasa sehingga proses pengadaan barang dan jasa lebih efektif dan efisien sehingga menjamin pemerintah untuk Saran mendapatkan hasil lelang terbaik melalui proses yang mudah dan cepat.

1. Pemerintah Provinsi Gorontalo agar melakukan penambahan kapasitas bandwith yang sesuai dengan jumlah pengguna yang telah melakukan registrasi dan penambahan server cadanganuntuk kebutuhan replikasi dan redundansi sistem aplikasi. 
2. Pemerintah Provinsi Gorontalo agar terus meningkatan kualitas informasi, kualitas sistem dan kualitas layanan oleh karena hal ini akan berpengaruh terhadap penggunaan dan kepuasaan pengguna terhadap layanan e-procurement dan berpengaruh pula pada peningkatan manfaat yang diperoleh dari penerapan e-procurement.

\section{Daftar Pustaka}

[1] K. Udoyono, "E-PROCUREMENT Murti, B.W; \& Adi, T.J.W. 2006. Analisa Kesenjangan antara Sistem Konvensional dan Sistem Elektronik pada Penyediaan Jasa Konstruksi di Pemerintah Kota Surabaya. Prosiding Seminar Nasional Manajemen Teknologi. Surabaya: ITS

[2] Nugroho, R. 2006. Studi Penjelajahan tentang Kebijakan Pengadaan barang/jasa melalui Internet di Departemen Pekerjaan Umum, Spirit Publik, Volume 2, Nomor 2. Indonesia: UNS http://www.fisip.uns.ac.id/publikasi/sp2_2_rino.pdf

[3] M. Chow, D. K. Herold, T.-M. Choo, and K. Chan, "Extending the technology acceptance model to explore the intention to use Second Life for enhancing healthcare education," Computers \& Education, vol. 59, no. 4, pp. 1136-1144, Dec. 2012.

[4] T. Farahat, "Applying the Technology Acceptance Model to Online Learning in the Egyptian Universities," Procedia - Social and Behavioral Sciences, vol. 64, pp. 95-104, Nov. 2012.

[5] Syarip, D.I; \& Sensuse, D.I, 2007. Kajian Penerimaan Teknologi Internet pada Organisasi Pemerintah berdasarkan Konsep Technology Acceptance Model (TAM): Studi Kasus Direktorat Jendeal Pendidikan Islam Departemen Agama R.I, Jurnal Sistem Informasi. Volume 3, Nomor 1, Jakarta: Universitas Indonesia

[6] N. Septifandari, "MEMBANGUN FITUR E-TENDERING PADA SISTEM INFORMASI EPROCUREMENT SEBAGAI BAGIAN DARI E-UNIVERSITY BERBASIS TEKNOLOGY JAVA EE MENGGUNAKAN METODE INTERATIVE DAN INCREMENTAL (Study Kasus: Institut Teknologi Telkom)," no. 24, pp. 7-9, 2013.

[7] Syarip, D.I; \& Sensuse, D.I, 2007. Kajian Penerimaan Teknologi Internet pada Organisasi Pemerintah berdasarkan Konsep Technology Acceptance Model (TAM): Studi Kasus Direktorat Jendeal Pendidikan Islam Departemen Agama R.I, Jurnal Sistem Informasi. Volume 3, Nomor 1, Jakarta: Universitas Indonesia 